\section{要旨}

1. 酸化鐵顏料の起原及び製造力法を晎にした試料 6 種に就き水分、鐵分、吸油量 Oil absorption, 盛込體積 Schüttvolum, 5 種の液體中の沈降體積 Sedimentrtion volume を測定した。5 種の液體の中四䜿化炭素、キシ ロールは非極性 nonpolar でありエチルアルコール、メ チルアルコール皮び氷は極性 polar である。

2. 水分及び鐵分 $\left(\mathrm{Fe}_{2} \mathrm{O}_{3}\right.$ として)の定量は JES の方 法、罗油量は Gardner-Coleman 兩氏支び ASTM の方法 に依り、盛込體積はメスシリンダーを用ふる方法、沈降 體積は顏料試料 $2 \mathrm{~g}$ をネスラー比色管に $25 \mathrm{cc}$ の液體と 共に探りよく振盪して 24 時間の後に沈降した顏料の體 積を䜋んだ。沈降試驗期間中の最高最低の溫度を記錄し て溫度差の極端に大きくないことを確めた。實驗結果は 一括して表に示してある。

3. 試料 1,2,4 は起原材料は何礼も硫酸鐵で $\mathrm{Fe}_{2} \mathrm{O}_{3}$
の含有量大きく, 水分, 吸油量, 盛込體積, 極性及び非 極性液體中の沈降體積, 極性及び非極性に對する沈降體 積の差暴の程度殆んど同一であつて、その差も著しくな く、主成分 $\mathrm{Fe}_{2} \mathrm{O}_{3}$ の性質が支配的である。試料 3 は $\mathrm{Fe}_{2} \mathrm{O}_{3}$ 分少く水分多く、黃土より作つたものであるが前 記の 3 試料とは諸性質を異にし、又試料 5 は硫化鐵鑛 の㯺きかすから作つた所謂小豆色酸化鐵又は錆粉と云ら、 もので、甚しく諸性質を異にする。試料 6 は鐵分極め て少く、之亦諸性質を異にする。

4. 要するにここに揭げた實驗數值は濱忪高等工業學 校學生山內辰夫君の夏期實㫘として得られたもので、期 間の制限から根本的に酸化鐵顔料の性質を檢討寸るには 量に於て不十分であつたが、この種の實驗が酸化鐵顏料 の檢討に有効で、且興味あるものであることを示した。 著者は將來に於てこの種の實驗を更に詳しく行ふつもり でむる。

\title{
On Some Properties of Iron Oxide Pigments.
}

M. Ishibashi, Yamato Toryo Kogyosho, Japan.

\section{Introduction}

Iron oxide pigment is important in paint trade because of its wide use. The author had an opportunity to examine the properties of the samples of diversified sources. The experimental data involved in this paper were obtained in a summer vacation exercise of a student of applied chemistry of Hamamatsu Technical College. Therefore, the amount of data obtained here is, unfortunately, rather limited in order to be able to discuss the matter fully. The writer shall have another cccasion to consider the same topics with satisfactory data in the near future.

The properties investigated here are oil absorption values, volumes of pigment "Schïttvolumen lose und gestampft", and sedimentation volumes in polar and nonpolar liquids.

\section{Samples Tested}

Six samples supplied by the courtesy of a manufacturer were of different or:gin and various manufacturing process, as given in the second column of the accompanying table. Analytical data as to the moisture and $\mathrm{Fe}_{2} \mathrm{O}_{3}$ presented in the third column of the tab'e were obtained by the methods of JES (1).

The pigments were sieved by the sieve of 120 mesh per square inch before examination. 


\section{Oil Absorption}

Various methods have been proposed for oil absorption measurement as shall be described later in this paper. The two were selected, that of Gardner and Coleman (2) and that of A.S.T.M. (3). In each case, 10 grams of pigment were taken and the raw linseed oil used had an acid value of 0.451 . The results are illustrated in the fourth column of the tab'e.

\section{Volumes of the Pigment}

The term "Schïttrolum lose", in this paper, means the volume in cubic centimeters occupied by 100 grams of the powders of lcose packing. "Schittvolum gestampft" represents the volume in c.c. of 100 grams of pigments in a cylinder after stamping. The above definitions are due to Becker (4). The writer messured these two kinds of pigment volume; the one by filling 250 c.c. measuring cyinder by spoon and reading the volume by the scale on the cylinder, and the other by letting fall the cylinder with 100 grams of pigment in it at a distance of $10 \mathrm{~cm}$ one hundred times on a rubber plate (5). The results are to be seen in the fifth column of the table.

\section{Sedimentation Volumes}

2 grams of pigment were taken in Nessler tubes w:th 25 c.c. of organic liquid and after shaking vigorously, the volumes of the settled pigment were noted after 24 hours, the maximum and minimum temperatures reached during this period being recorded by means of maximum and minimum thermometer. Organic liquids used were as follows: carbon tetrachloride, xylene (non polar). methyl alcohol, ethyl alcohol and distilled water (polar). Before use, these liquids were subjected to distillation. The results of observation are listed in the sixth column of the table.

\section{Discussion}

Analyses show, as illustrated in the table, that the samples 1,2 and 4 whose contents of $\mathrm{Fe}_{2} \mathrm{O}_{3}$ exceed 94 per cent contain nearly the same amount of moisture. These three specimens were made from iron sulfate while the others with different starting materials have less iron oxide and reveal high moisture contents especially the sample 6 of the least iron content.

Oil Absorption.

Oil absorptions by the two methods show that the methcd of Gardner and Coleman gives the higher values than those obtained by the A.S.T.M. method in every case. But the values by the latter, if divided by the specific gravity of the oil, to make the data comparable, approach the former. Samples 1, 2 and 4 whose iron content exceed 94 per cent have almost the same values. The sample 3 made from cohre shows the highest and the sample 5 from pyrite cinder the lowest value.

"Schüttrolumen"

Here appears again a similarity as seen in the case of oil absorption, that is, samp'e 1,2 and 4 have the same order of magnitude as to the "Schüttvolumen" and the sample 4 the greatest and the samp?e 5 the least.

\section{Sedimentation volumes.}

Sample 3 shows the highest value and samp'e 5 the lowest in every medium. And the three samples 1, 2 and 4 indicate almost the same mannitude as to sedimentation volumes for each liquid. These three samples behave in the similar way as seen in oil absorption and "Schüttvolumen."

The readers are now required to see the numerical data shown in the sedimentation volume column of the table from left to right and it will be found that in nonpolar liquids such as carbon tetrachloride and $\mathrm{xy}$ lene the volumes are larger than in polar liquids $i$. e. alcohols and water. Samp'e. 3,5 and 6 show widest difference as to the polarity of the liquids and their iron contents are less than the others which show difference due to the polarity of the liquid; to a slighter extent and, in addition, have approximately the same value as to each liquid.

'The interdependent properties, i. e. oil absorption, "Schütvolumen" and sedimentation volumes, or more generally speaking, the interreiation of solid powder and liquid with respect to interface phenomena have been fascinating topics of the paint profession. Accor- 
dingly, a vast amount of literature have been presented.

Measurement of the numerical values of oil absorption or, more broadly, liquid absorption of pigment powders has been a common practice in paint industry in order to get a rough picture for relationship between pigment and vehicle, for the method of measurement requires no complicated mechanism or apparatus. The accuracy of the results, however, is a matter of dispute in spite of the simplicity of the procedure and no fair agreements have been attained by different methud a: d different experimenter.

Benard (6), Hougen and Hentzen (7), Gardner, Fasig, Gardner and Coleman, Ingall (\&), Wagner and Pfanner (9), Wolff (10), Bartell asd Hershberger (11), Jakubowitz and Goldberg (12) proposed their own methods or modified the methods of cthers.

It is generally accepted that the oil absorption values of the same sample of pigment by different methcds never show close agreement and it is said, "the oil absorption values are a function of the method of measurement." The two methods adopted by the author are mcst widely used and familiar ones in paint trade.

It is generally conceded that oil absorption is controlled by two main factors i. e. magnitude of the specific surface of the powder and the wetting or more accurately the interfacial force characteristic between the solid and the liquid.

Klumpp (13) ins:sted on his opinion that the oil absorption values of pigments depend solely on the pore volumes. The defects in Klumpp's idea were pointed cut by Grohn (14) and Wagner (15). And more recently Wagner (16) presented again a controversy saying to the effect that, of the two dominant factors governing oil absorption, "Intensitätsfaktor" and "Karazitätsfaktor", the former was totally neglected in his reasoning.

From the experimental data showing the additive qua'ity of the oil absorption of the pigment mixtures, Baldwin (35) supports the idea that the specific surface is one of the important factors in oil absorption phenomena. Gardner pointed out that the oil absorption value is relative to the specific surface of the pigment powders.

As the wetting relations existing between liquid and pigment powder, American investigators published the data thereof and confirmed that the wetting phenomen: is one of the important factors involved in the evalution of liquid absorption. Bartell and his co-workers (17) with their sccalled Bartell cell, and Harkins and his assistants (18) with their ingeneous method of determination of heat of wetting revealed the valuable facts concerning the wetting phenomena of the pigments. On the other hand, German workers, Grohn (19), Geret (20) and others studied the relations between wetting ard liquid absorption.

De Waele and Lewis (23), Haller (24) from theoretical considerations and McMillen (25) from his Bartell cell experiments pictured the actions of the surface furce of the pigmen: toward the surrounding liquid. It was concluded by these workers that good wetting resulted in slow settling and high liquid absorption when the adsorbed layer of the liquid was formed on the pigment surface. Quite recently C. Mack showed that the settling volumes of powdered solid in various liquids is a function of the adhesion tension of the liqu:d against water.

Harkins and Dahlstrom pointed cut that settling is not a simple function of wetting since water and polarnonpolar organic substances wetting the pigment remarkably weil and exhibit exactly opposite effects.

In considering surface phenomena between solid and liquid not only the liquid phase but also the solid phase must be taken into account. Pigments can be classified into two groups: oxcphile and carbophile, in other words, polar and nonpoldr. Iron oxide as well as the other oxide pigments belongs to oxophilic kind.

According to Geret, polar liquids wet polar pigments better than nonpolar pigments and this fact probably results in deflccculation of the aggregated pigment particles and causes good settling. In the above case, the volumes of sedimentation are small. Poor wetting, on the other hand, as described by Sulman (21), Jolly (22) give rise to flocculation of pigment particles and consequently litt'e settling.

A fatty acid molecule consists of a polar group $\mathrm{COOH}$ and nonpolar group $\mathrm{C}_{\mathrm{x}} \mathrm{H}_{\mathrm{y}}$ and its polarity is scmewhat pr(nounced. Harkins, Hardy and Langmuir constructed the scca'led Langmuir-Harkins' theory of orientation 
of the fatty acid molecules at the interface of pigments with liquids. Harkins and Dahlstrom (27) studied the relation of wetting of the pigment to the liquids containing a small amount of fatty acid.

The behaviour of fatty acid in oil absorption is different according to the kind of pigment and liquid, the amount ard the method of determination of oil absorption. These authors agree in conclusion that there is a break $p$ int at which the rate of variation of oil absorption against the acid content of the oil used suddenly becomes greater on the oil absorption acid value curves. It is, therefore, neccesary to work within th's limit of acid value as recommended by Gardner who specified that the oil to be used in oil absorption shculd have the acid value between 1.0 and 3.0. From the above descriptions, it will be easily seen that oil absorpticn is affected by wetting relation of pigment and consequently the free acid contained in the oil used.

Effects of free acid on the oil absorption have been reported by a number of investigators, namely, Calbeck (28), Gardner (29), Grohn (30), Williamson (31), Centner (3), Scheiber and Rottsahl (33), Jakubowitz and Goldberg (34).

Acid values of the linseed oil samples stored in the author's laboratory were determined, the values were $0.451,1.55,0.436,2.10$ and 0.885 and in this series of experiments the oil of acid value 0.451 was used.

Among the samples tested, No. 1, 2 and 4 contains about the same amount of iron oxide and give almost the same values as to "Schüttvolumen", moisture content, oil absorption exepting that the sedimentation volumes of No. 4 in nonpolar liquids are very small relative to the other two. These results lead to cons.deration that the dominant factor controlling these qualities of the iron oxide pigment is the content of iron. The marked difference in sedimentation volumes in polar and nonpolar liquids indicates that the samp'es have the characteristic property of oxophilic pigment.

The sample 3 contains a somewhat large amount of moistrue and the content of iron is lower than those of No. 1, 2 and 4. Oil absorptions, "Schüttvolumen" and sedimentation volumes have higher values and the difference of sedimentation volume due to the polarity of the suspanding liquids is the greatest of all the samples tested. The unknown constituent, as far as this experiment concerned, may be strongly oxophilic.

Sample 6 containing low percentage of iron and highly moistened indicates comparatively small sedimentation volumes in polar liquids and $\operatorname{lar}_{\delta}$ e difference due to the polarity of the liquids. In this instance, also, the strongly oxophilic nature may. be attributed to the component other than iron.

Samp'e 5 whose $\mathrm{F}_{2} \mathrm{O}_{3}$ content is of the same order of the magnitude as the sample 3 revealed that the oil absorption, "Sch ittvolumen" and sedimentation volumes both in polar and nonpolar liquids are higher than those of the other samp'es of higher iron content. These behaviours, perhaps, are due to the larger particle size which is seen from the low "Schüttvolumen." "Schüttvolum" can be considered as an sedimentation volume in air corresponding in sorne way to the pore volume of the pigment which is one of the main controlling factors of oil absorption values.

Comparing the data as to the samples $1,2,3,4$ and 5 , it will be seen that there exists a parallellism between the "Schüttevolumen" and oil absorptions. In this respect sample 6 has a comparatively small oil absorption value notwithstanding the higher "Schüttvolumen" and marked difference of sedimentation volumes in polar and nonpolar liquids. This anomalons case may be explained by the presence of the other constituent than iron to a remarbable extent.

\section{Summary}

1. Six samples of iron oxide pigments of different sources were examined as to the following properties:

(a) "Schüttrolumen lcse und gestampft"

(b) Oil absorption with raw linseed oil of acid value 0.451 by the methods of Gardner and Coleman and A.S.T.M.

(c) Sedimentation valumes in carbon tetrachloride, xylene, ethyl- and methyl-alcohols, and distilled water.

2. Quantities of moisture and iron as $\mathrm{Fe}_{2} \mathrm{O}_{3}$ were obtained by analysis.

3. The correlation of the properties mentioned above and the compositions of the pigment were discussed.

4. The data obtained are rather scarce in order to form a clear and precise picture of the pigmental pro- 
perties of iron cxide pigments. The properties enumerated above and determination of them afforded valuable data which predict that further investigations on these problems may be rery useful in obtaining suggestive inform tions about the pigmental characteristic of the iron oxide pigment.

\section{Acknowledgement}

Thə measurements included in this paper were carried out, as started at the beginning of this paper, by Mr. Yamanouchi, a student of applied chemistry of Hamamatsu Technical College, for whose dilligent and faithful assistance cannot be thanked too much by the writer.

\section{Literature Cited}

(1) J.E.S. No. 148.

(2) Gardner and Scheifele, Untersuchungsmethoden S. 265.

(3) A.S.T.M. Standards on Preservative Coatings for Structural Materials.

(4) Becker, Farben Ztg. 38, 62, 1685.

(5) Gardner and Scheifele, Untersuchungsmethcden S. 139 .

(6) Benard, Paint Oil and Chemical Review, 70, 8 (1920)

(7) Hougen and Ientzen, Chem. Net. Eng. 2?, 840 (1923)

(8) These five methods are described in Gardner and Scheifele's book.

(9) Farben Ztg. 34, 2513.

(10) Wolff, Zeidler and Toeldte, Farben Ztr. 33, 2730.

(11) B.rtell and Hershberger, Ind. Eng. Chem. 22, 12,
$1304(1930)$.

(12) Farben Ztg. 38, 48, 1312.

(1F) Klunupp, Farben Ztg. 32, 2306; 37, 1290.

(14) Grohn, Farben Ztg. 32, 1660.

(15) Wagner and Pfanner, Farben Ztg. 24, 2513.

(16) Wagner, Farben Ztg. 42, 83.

(17) Bartell and Greager, Ind. Eng. Chem. 21, 12, 1248. Bartell and Hershberger, ibid, loc. cit. Bartell and Smith, ibid, 21, 12, 1196. McMillen, ibid, 21, 12, 1237.

(18) Ryan, Harkins and Gans, ibid, 24, 11, 1288. Harkins and Dahlstrom, ibid, 22, 8, 897 .

(19) Grohn, loc. cit.

(20) Geret, Farben Ztg. 37, 586.

(21) Bull. Inst. Min. Met. 182, (1929).

(22) J. Oil Col. Chem. Ass. 11, 361 (1928).

(23) Kolloid Zeitsch. 48, 126 (1929).

(24) ibid. 46, 366 (1928).

(25) loc. cit.

(26) C. Mack, Ind. Enr. Chem. 27, 12, 1500 (1935).

(27) Harkins and Dahlstrom, loc. cit.

(28) Calbeck, Chem. Met. Eng. 31, 377 (1924).

(29) Gardner and Scheifele, Untersuchungsmethoden S. 265.

(30) Grohn, Farben Ztg. 33, 1660.

(31) Williamson, Ind, Eng. Chem., 21, 1196 (1929).

(32) Centner, Farben Ztg. 37, 340 (1931).

(33) Scheiber and Rottsahl, Farbe und Lack, Nr. 27, 315 (1934).

(34) Jakubowitz and Goldberg, Farben Ztg. 38, 48, 1312.

(35) Baldwin, Ind. Eng. Chem. 21, 4, 326 (1929).

Dita as to the Composition, Moisture Content, Oil Absorption, „Schüttrolumen “, and Sedimentation Volumes of the Six Specimens of Iron Oxide Pigment.

\begin{tabular}{|c|c|c|c|c|c|c|c|c|c|c|c|c|}
\hline \multirow[t]{3}{*}{ Sample } & $\begin{array}{l}\text { Starting } \\
\text { Material }\end{array}$ & $\begin{array}{r}\text { Anal } \\
\text { Moisture }\end{array}$ & $\begin{array}{l}y s i s \\
\mathrm{~F}_{2} \mathrm{O}_{3}\end{array}$ & $\begin{array}{l}\text { Oil abso } \\
\text { Gardner- } \\
\text { Coleman }\end{array}$ & $\begin{array}{l}\text { orption } \\
\text { A.S.T.M. }\end{array}$ & Schüt & ttvolumen & & Sedimenta & tion & lumes & \\
\hline & & $\%$ & $\%$ & $\mathrm{cc} / 100 \mathrm{~g}$ & $\mathrm{~g} / 100 \mathrm{~g}$ & & $100 \mathrm{~g}$. & & ec 1 & $2 \mathrm{~g}$ & & 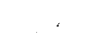 \\
\hline & & $\therefore$ & . & 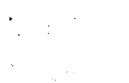 & ; . & lose & gestampft & $\begin{array}{l}\text { Carbon- } \\
\text { Tetrach- } \\
\text { loride }\end{array}$ & Xylene & $\begin{array}{l}\text { Methyl } \\
\text { Alcohol }\end{array}$ & $\begin{array}{l}\text { Ethyl- } \\
\text { Alcohol }\end{array}$ & Water \\
\hline 1. & $\begin{array}{l}\text { Iron } \\
\text { sulphate }\end{array}$ & 0.21 & 97.4 & 55.7 & 47.5 & 158 & 104 & 4.10 & 3.92 & 3.04 & 3.02 & 4.50 \\
\hline$\therefore 2$ & $\begin{array}{l}\text { Green } \\
\text { vitriol }\end{array}$ & 0.26 & 94.2 & 57.9 & 52.4 & 153 & 109 & 4.10 & 3.91 & 3.08 & 2.89 & 4.10 \\
\hline 3 & Ochre & 1.91 & 84.4 & 91.7 & 79.5 & 258 & 143 & 11.1 & 6.42 & 3.92 & 3.65 & 4.53 \\
\hline 4 & $\begin{array}{l}\text { Iron sul- } \\
\text { phate* }\end{array}$ & 0.26 & 94.4 & 55.3 & 43.9 & 152 & 112 & 8.75 & 3.61 & 3.09 & 2.92 & 3.06 \\
\hline
\end{tabular}


[第 9 號]

報文...凟料

201

\begin{tabular}{|c|c|c|c|c|c|c|c|c|c|c|c|}
\hline $\begin{array}{l}\text { Pyrite } \\
\text { cinder }\end{array}$ & 0.65 & 81.5 & 26.0 & 22.9 & 92 & 66 & 3.39 & 3.00 & 1.51 & 1.30 & 1.68 \\
\hline Sludge $e^{* *}$ & 8.40 & 52.0 & 49.3 & 41.9 & 161 & 103 & 6.09 & 5.34 & 2.70 & 2.40 & 2.87 \\
\hline rature $\left({ }^{\circ} \mathrm{C}\right)$ & & & & & & & $\begin{array}{r}27.7^{\circ} \sim \\
34.8^{\circ}\end{array}$ & $\begin{array}{r}28.4^{\circ} \sim \\
35.7^{\circ}\end{array}$ & $\begin{array}{r}27.0^{\circ} \sim \\
36.0^{\circ}\end{array}$ & $\begin{array}{r}26.4^{\circ} \sim \\
36.0^{\circ}\end{array}$ & $\begin{array}{r}27.4^{\circ} \sim \\
33.1^{\circ}\end{array}$ \\
\hline
\end{tabular}

*Calcined in reverberatory furnace.

** Jlud zुe obtained in levigation process and composed of impure iron oxide of various origins.

\section{凟料}

\section{市販石油製品の比重粘度及屈折率}

內閣印刷局矿究所 小 倉 正 照

過般石泊彆品規格 (日本標準嫢格 173 號)が制定された 際著者は日本石油會社に於て新嫢格に適合せしめて調製 せる見本各種並に該替格によつて戡入せる市販品に就て

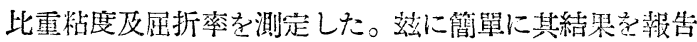
する。

試料 試料は.上述の通り此實澰用として日本石油會社 に於て調製せる見本 33 種と該嫢格によつて䝼大せる市 販品 (內2 種を除き何れも同社製) 18 種外に單に市販名 によつて購入せるへルモン 1 種である。

測定注 比重の测定は比重爆 ( $50 \mathrm{cc}$ 容量) 使用し屈 折率の測定には Abbe の屈折計を用るた。测定溫度は何 れも $25^{\circ}$ である。粘度の測定には右圖に示声樣な粘度 計を用みた。即ち圖に於て $30 \mathrm{cc}$ の目盛り迄試料を入れ 密栓して恒溫槽中に浸漬し $25^{\circ} \mathrm{C}$ に保つた後試料を內管 中に吸ひ上げ約 $8 \mathrm{cc}$ の液が細管(長さ約 $12 \mathrm{~cm}$ ) を通じ て流下寸る時閒を求め次式により絕對粘度ポイズ posse に算出した。

\begin{tabular}{|c|c|c|c|c|c|c|}
\hline $\begin{array}{l}\text { 試料 } \\
\text { 番號 }\end{array}$ & 新規格による名稱 & 比重 & 粘度 & 屈折菜 & 市販各 & 考 \\
\hline & 燃料 油 & & & & & \\
\hline 1 & 第1 種第2 號(航空機用揮發油) & 0.6771 & 0.0035 & 1.3833 & 1 號揮發油 & 米國虐、日石鶴見製油所製 \\
\hline $2^{*}$ & 第 2 種第 1 號(自動車用揮發油) & 0.7098 & 0.0043 & 1.4010 & 不明 & (小畣石油䕥。主溜分 $51^{\circ}-149^{\circ}$ ) \\
\hline $3 *$ & (同上) & 0.7178 & 0.0044 & 1.4060 & 特 2 號揮發油 & (主溜分 $64^{\circ}-145^{\prime}$ ) \\
\hline $4 *$ & (同上) & 0.7182 & 0.0016 & 1.4070 & 同上 & (主溜分 $65^{\prime}-170^{\circ}$ ) \\
\hline 5 & (同上) & 0.7315 & 0.0048 & 1.4115 & 同上 & 米國座、鶴見製油所製(主溜分 $75^{\prime}-154^{\circ}$ ) \\
\hline 6 & 第 2 種第 2 號(同上) & 0.7323 & 0.0049 & 1.4165 & 赤揮發油 & 同上(主溜分 $75^{\circ}-210^{\circ}$ ) \\
\hline 7 & 第 2 種第 3 號(同上) & 0.7197 & 0.0046 & 1.4135 & 同上 & 同上 \\
\hline 8 & 第 2 種第 4 號(同上) & 0.7380 & 0.0051 & 1.4213 & 2 號揮發油 & 同上 \\
\hline 9 & 第 3 種第 1 號(燈油) & 0.8145 & 0.014 & 1.4525 & 白蝠䉚油 & 同上(引以點 $38^{\circ} 、$ 主溜分 $160^{\circ}-254^{\circ}$ ) \\
\hline $10 \%$ & (同上) & 0.8166 & 0.018 & 1.4563 & 同上 & \\
\hline
\end{tabular}

茲で $\eta=$ 絕對粘度ポイズ $\kappa=$ Poiseuille の式による恒數

$$
\frac{\pi r^{4}}{8 \mathrm{~V} !} \mathrm{h} .
$$$$
\rho=\text { 比電 }
$$

但し๙はベンゾール $(\mu=0.005999)$ 水 $(\mu=0.00894)$ 並に種々の濃度の グリセリン溶液の粘度 (M.L. Sheely， Ind. Eng. Chem., 1932,24,1060) を標 準とし此物の流下時間 $t_{0}$ を求め次式 により算出した。

$$
\kappa=\frac{\eta_{0}}{\rho_{0} t_{0}}
$$

沿測定には液の粘度に應じて 3 種の太さの細管を用る た。

結果 测定した結果は次表に一括して示す。 